\title{
The human genes for complement components 6 (C6) and 9 (C9) are closely linked on chromosome 5
}

\author{
Sissel Rogne, Ola Myklebost, Johan H Olving, Heidi Tomter Kyrkjebø, Reidun Jonassen, \\ Bjørnar Olaisen, Tobias Gedde-Dahl Jr
}

\begin{abstract}
We have used a cDNA probe for human complement component 9 (C9), which detects three DNA polymorphisms, to analyse the inheritance of $\mathrm{C9}$ in families informative for $\mathrm{C6}$ protein variants. We found that these genes are closely linked with a lod score of $9 \cdot 28$ at recombination fraction 0.00 . There is no indication of allelic association.
\end{abstract}

Cytolysis mediated by the complement factors is a complex cascade reaction where the final membrane lesion is caused by the polymerisation of complement component 9 (C9) into cylindrical pores. The C9 pore formation can only take place in the presence of a receptor-like complex, the membrane attack complex (MAC), which is formed after the cleavage of $\mathrm{C} 5$ into $\mathrm{C} 5 \mathrm{a}$ and $\mathrm{C} 5 \mathrm{~b}$, where $\mathrm{C} 5 \mathrm{~b}$ reacts with C6 followed by $\mathrm{C} 7$ and C8 (for review, see Müller-Eberhard').

The terminal complement components belong to a family of proteins with highly conserved cysteine

Department of Animal Science, Agricultural University, PO Box 25, N-1432 Ås-NLH, Norway. S Rogne

Department of Tumor Biology, Institute for Cancer Research, Norwegian Radium Hospital, 0310 Oslo 3, Norway.

O Myklebost

Institute of Forensic Medicine, University of Oslo, Rikshospitalet, 0027 Oslo 1, Norway.

$\mathrm{J}$ H Olving, R Jonassen, B Olaisen

Department of Genetics, Institute for Cancer Research, Norwegian Radium Hospital, 0310 Oslo 3, Norway.

H T Kyrkjebø, T Gedde-Dahl Jr

Polar Institute of Medical Genetics, Regional Hospital and University of Tromsø, N-9000 Tromsø, Norway.

T Gedde-Dahl Jr

Correspondence to Dr Rogne.

Received for publication 21 December 1990.

Accepted for publication 3 April 1991. rich domains, related to perforin, thrombospondin, low density lipoprotein (LDL) receptor, epidermal growth factor (EGF) precursor, and low density lipoprotein receptor related protein LRP. ${ }^{23}$ The shared homology between the genes indicates an evolutionary cut-and-pasting.

The complement component genes are located on several of the chromosomes. The genes for the two subcomponents of $\mathrm{Cl}$ are on chromosomes 1 and 12, whereas the genes for $\mathrm{C} 2, \mathrm{C} 3, \mathrm{C} 4, \mathrm{C} 5, \mathrm{C} 8$ ( $\mathrm{A}$ and $\mathrm{B}$ ), and $\mathrm{C} 9$ are on chromosomes $6,19,6,9,1$, and 5 , respectively..$^{4-14}$ Recently $\mathrm{C} 6$ and $\mathrm{C} 7$ have also been assigned to chromosome $5 .{ }^{15}$ We now report close linkage between $\mathrm{C} 6$ and $\mathrm{C} 9$.

\section{Materials and methods \\ C9 ANALYSIS}

A fragment reconstituted from cloned cDNAs was used as a probe for the human $\mathrm{C} 9$ gene. The probe spanned from the $5^{\prime}$ end of clone $C 9-30$ to the $3^{\prime}$ end of clone C9-26 and contained the entire coding sequence for human C9. ${ }^{16}$ After separation on an agarose gel, the fragment was purified by the use of a DEAE membrane (Schleicher \& Shuell NA45) and labelled by random primed synthesis.

DNA was isolated from leucocytes, and $7 \mu \mathrm{g}$ samples were digested with $T a q \mathrm{I}$, separated electrophoretically on $0.8 \%$ agarose gels, and blotted onto nylon membranes as previously described. ${ }^{17}$ The blots were hybridised to the probe in $5 \times$ SSC, $100 \mu \mathrm{g} / \mathrm{ml}$ salmon sperm DNA, 5\% dextran sulphate, and $1 \%$ SDS overnight at $65^{\circ} \mathrm{C}$ and washed down to $0.2 \times \mathrm{SSC}\left(30 \mathrm{mmol} / 1 \mathrm{Na}^{+}\right)$at $65^{\circ} \mathrm{C}$. Autoradiographs were made by exposure of $x$ ray film (Kodak XAR-5) to the filters for 16 to 40 hours at $-70^{\circ} \mathrm{C}$ with intensifying screens (Agfa MR400). The TaqI polymorphisms with the alleles A1,A2 $(7.6 \mathrm{~kb}, 6.6 \mathrm{~kb})$ and $\mathrm{B} 1, \mathrm{~B} 2(14 \mathrm{~kb}, 16 \mathrm{~kb})$ have been described previously. ${ }^{18} \mathrm{We}$ report here a $9.5 \mathrm{~kb}$ fragment (allele $\mathrm{C}+$ ) scored as a Mendelian dominant.

\section{C6 ANALYSIS}

C6 typing was performed by high voltage agarose gel electrophoresis. ${ }^{1920}$ Bands of $\mathrm{C} 6$ activity were visualised using the techniques described by Hobart et $a l^{21}$ 


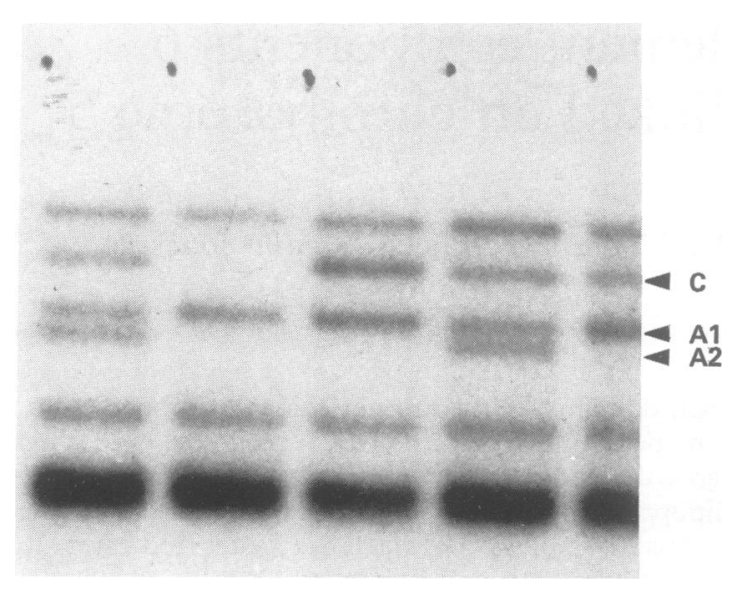

Figure 1 Autoradiograph showing gene fragments hybridising to the $C 9 \mathrm{cDNA}$ probe after genomic $D N A$ from different subjects were digested with TaqI, separated on an agarose gel, and blotted onto a nylon membrane.

with a haemolysis-in-gel assay with sensitised sheep red cells and C6 deficient rabbit serum. Parts of the material (including all subjects informative for $\mathrm{C} 9$ ) have also been typed by isoelectric focusing gel electrophoresis. $^{21}$

\section{FAMILY MATERIAL}

The families studied are part of the Oslo NHIK family material, which has been tested for more than 40 polymorphic markers. ${ }^{22}$ Families informative for the $\mathrm{C} 6$ protein polymorphism have been tested for the C9 RFLPs.

\section{LOD SCORE ANALYSIS OF FAMILY DATA}

The lod scores were calculated according to Morton, ${ }^{2324}$ and lod scores for all recombination fractions $0.00,0.01$ to 0.49 calculated by the MOSM computer program developed by Dan Wøien (Norwegian Computing Centre, Oslo 3, Norway) in 1970.

\section{Results}

The restriction enzyme TaqI detects multiple RFLPs. Two of these (A and B) have been characterised previously. ${ }^{18}$ The third RFLP has been verified as a Mendelian dominant trait (allele $\mathrm{C}+$ ) in this study. The other allele probably appears as recessive because its position on the blot overlaps one of the invariant bands. The RFLPs used here are therefore numbered A1A2, B1B2, and C according to the recommendations of Skolnick et al. ${ }^{25}$ The RFLPs are shown in fig 1 and, a priori, the three RFLPs are in the same locus. Consistent with this, all give positive lod scores without recombination with C6 (table 1). When no recombination is found, the upper $90 \%$ confidence limit of the recombination fraction can be derived the simplest as $\ln 10$ divided by the number of informative meioses. ${ }^{24}$ When accepting 20 informative male and 18 informative female meioses as non-recombinant for the C6:C9 relation (two $\mathrm{z}_{2}$ score families ${ }^{23}$ each with two children not being scorable), the limit is $\theta=0.06$ (ln10/38). This coincides with the confidence limit obtained as the $\theta$ at which the lod score is equal to the maximum minus one. ${ }^{26}$

Fig 2 shows the inheritance of the C6 protein and C9 DNA polymorphisms in a large family. Apart from the $\mathrm{C} 9 \mathrm{C}+$ allele discussed above, the $\mathrm{C} 6$ and C9 polymorphisms show normal codominant inheritance and no recombination has been found so far. The combined results from the seven families give a lod score for linkage of 9.28 at recombination fraction 0.00 (table 1). The C6-C9 haplotypes of the independent subjects are presented in table 2 . There is no suggestion of allelic association.

Between the A1A2 alleles and the presence or absence of the $9.5 \mathrm{~kb} \mathrm{C}+$ band there is strong linkage disequilibrium. So far no subject with the haplotype A2C - has been found (absent C band $=\mathrm{C}-$ ), 16 have $\mathrm{AlC}-$, three have $\mathrm{AlC}+$, and seven have $\mathrm{A} 2 \mathrm{C}+$. By adding up the data from Rogne et al,${ }^{18}$ we get allele frequencies of $\mathrm{Al}=58 \%$, $\mathrm{A} 2=42 \%, \mathrm{~B} 1=93 \%, \mathrm{~B} 2=7 \%, \mathrm{C}+=58 \%$, and $\mathrm{C}-=42 \%$ (calculated as the square root of the number of subjects with $\mathrm{C}+$ divided by the total number of informative subjects).

Table 1 Linkage relationships between C6 and C9. The female and male meioses informative for C6 and C9 were counted separately and combined for the linkage analysis.

\begin{tabular}{|c|c|c|c|c|c|c|c|c|c|}
\hline \multirow[t]{2}{*}{ Sex } & \multirow{2}{*}{$\begin{array}{l}\text { No of } \\
\text { families }\end{array}$} & \multirow{2}{*}{$\begin{array}{l}\text { No of } \\
\text { children }\end{array}$} & \multicolumn{7}{|c|}{ Lod score at recombination fraction } \\
\hline & & & 0.00 & 0.01 & 0.05 & $0 \cdot 10$ & 0.20 & 0.30 & 0.40 \\
\hline $\begin{array}{l}\text { Males } \\
\text { Females } \\
\text { Both* }\end{array}$ & $\begin{array}{l}5 \\
3 \\
7\end{array}$ & $\begin{array}{l}20 \\
22 \\
35\end{array}$ & $\begin{array}{l}4 \cdot 52 \\
4 \cdot 77 \\
9 \cdot 28\end{array}$ & $\begin{array}{l}4 \cdot 43 \\
4 \cdot 70 \\
9 \cdot 13\end{array}$ & $\begin{array}{l}4 \cdot 07 \\
4 \cdot 44 \\
8 \cdot 51\end{array}$ & $\begin{array}{l}3 \cdot 61 \\
4 \cdot 09 \\
7 \cdot 70\end{array}$ & $\begin{array}{l}2 \cdot 64 \\
3 \cdot 26 \\
5 \cdot 90\end{array}$ & $\begin{array}{l}1 \cdot 60 \\
2 \cdot 28 \\
3 \cdot 88\end{array}$ & $\begin{array}{l}0.51 \\
1 \cdot 11 \\
1 \cdot 68\end{array}$ \\
\hline $\begin{array}{l}\text { C6:A1A2† } \\
\text { C6:B1B2 } \\
\text { C6:C+ }+\end{array}$ & $\begin{array}{l}3 \\
2 \\
3\end{array}$ & $\begin{array}{r}26 \\
5 \\
22\end{array}$ & $\begin{array}{l}6.92 \\
0.90 \\
2 \cdot 25\end{array}$ & $\begin{array}{l}6 \cdot 81 \\
0 \cdot 88 \\
2 \cdot 20\end{array}$ & $\begin{array}{l}6 \cdot 37 \\
0 \cdot 79 \\
2 \cdot 00\end{array}$ & $\begin{array}{l}5 \cdot 78 \\
0 \cdot 68 \\
1 \cdot 74\end{array}$ & $\begin{array}{l}4 \cdot 50 \\
0 \cdot 45 \\
1 \cdot 18\end{array}$ & $\begin{array}{l}3.05 \\
0.23 \\
0.62\end{array}$ & $\begin{array}{l}1.40 \\
0.07 \\
0.16\end{array}$ \\
\hline
\end{tabular}

* One family (fig 2) scored with seven children from the father and 18 children from the mother.

† Same families contributing. 


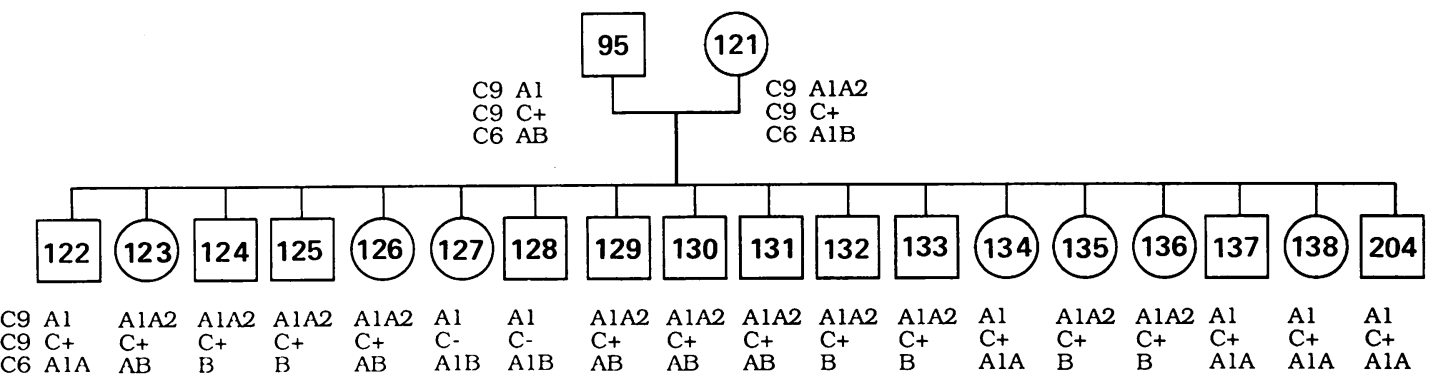

Figure 2 Pedigree of a family informative for C6 protein polymorphism ( $A, A 1$ and $B)$ and both the C9 $A$ and $C$ RFLPs with TaqI $(A 1, A 2$ and $C+, C-)$.

Table 2 C6:C9 haplotypes in unrelated subjects.

\begin{tabular}{lcc}
\hline Allele & C9 A1 & C9 A2 \\
\hline C6 A & 15 & 8 \\
C6 A1 & 1 & 7 \\
\hline
\end{tabular}

\section{Discussion}

The genes for the terminal complement components $\mathrm{C} 6, \mathrm{C} 7$, and $\mathrm{C} 9$ have recently been localised to chromosome $5,{ }^{14} 15$ whereas those for C8A and B are on chromosome $1 .{ }^{1213} \mathrm{We}$ now report close linkage between $\mathrm{C} 6$ and $\mathrm{C} 9$, with a maximum lod score of 9.3 at zero recombination frequency, well above the value of 3 which is ordinarily accepted as proof of linkage. The number of unrelated subjects is too low to draw any firm conclusions about linkage disequilibrium between $\mathrm{C} 6: \mathrm{C} 9$ haplotypes. However, the data indicate linkage equilibrium between the loci, and may be added to data from other groups.

The $\mathrm{C} 6$ and $\mathrm{C} 7$ genes have previously been shown to be closely linked. ${ }^{27} 28$ The close linkage of these two genes and C9 suggests a cluster of complement genes within a small area of chromosome 5 , as has similarly been found for some structurally and functionally related genes, for example, some of the apolipoprotein genes. ${ }^{2930}$ Assuming the genes are localised in a gene cluster, it would be of great interest to construct a physical map of the region spanning the $\mathrm{C} 6, \mathrm{C} 7$, and $\mathrm{C} 9$ genes with the aid of pulsed field gel electrophoresis.

We are grateful to Dr Keith Stanley for providing the $\mathrm{C} 9$ probe.

1 Müller-Eberhard HJ. The membrane attack complex of complement. Annu Rev Immunol 1986;4:503-28.

2 Stanley KK, Luzio P. A family of killer proteins. Nature 1988;334:475-6.

3 Herz J, Hamann U, Rogne S, Myklebost O, Gausepohl H, Stanley KK. Surface location and high affinity for calcium of a $500 \mathrm{kDa}$ liver membrane protein closely related to the LDL- receptor suggest a physiological role as lipoprotein receptor. $E M B O$ f 1988;7:4119-27.

4 Hedge PJ, Seller GC, Reid KBM, Solomon E. Assignment of the $\mathrm{A}$ chain of $\mathrm{Clq}$ (C1QA) to the short arm of chromosome 1 . Cytogenet Cell Genet 1987;46:627.

5 Solomon E, Skok J, Griffin J, Reid KBM. Human C1qB chain (C1QB) is on chromosome 1p. Cytogenet Cell Genet 1985;40:749.

6 Cohen-Haguenauer O, Serero S, Tosi M, et al. Chromosomal assignment of human $\mathrm{Cl}-\mathrm{R}, \mathrm{Cl}-\mathrm{S}$ genes on chromosome 12 and $\mathrm{Cl}$ inhibitor gene on chromosome 11. Int Congr Hum Genet 1986;7:617A.

7 Day HK, L'Esperance P, Good RA, et al. Hereditary C2 deficiency: genetic studies and association with the HLA system. F Exp Med 1975;141:1464-9.

8 Whitehead AS, Solomon E, Chambers S, Bodmer WF, Povey S, Fey GH. Assignment of a structural gene for the third component of human complement to chromosome 19. Proc Natl Acad Sci USA 1982;79:5021-5.

9 Teisberg P, Akesson I, Olaisen B, Gedde-Dahl T Jr, Thorsby E. Genetic polymorphism of $\mathrm{C} 4$ in man and localisation of a structural C4 locus to the HLA gene complex of chromosome 6. Nature 1976;264:253-4.

10 Jeremiah SJ, West LF, Davis MB, Povey S, Carritt B, Fey GH. Assignment of human complement component $\mathrm{C} 5$ to chromosome 9. Cytogenet Cell Genet 1987;46:634.

11 Lemons RS, Le Beau MM, Tack BF, Wetsel RA. Chromosomal mapping of the gene encoding the fifth component of human complement. Cytogenet Cell Genet 1987;46:647.

12 Rogde S, Mevăg B, Olaisen B, Gedde-Dahl T Jr, Teisberg P. Structural gene(s) for complement factor C8 (C8) on chromosome 1. Cytogenet Cell Genet 1983;37:571.

13 Rogde S, Olaisen B, Gedde-Dahl T Jr, Teisberg P. Two complement component C8 loci are localized between PGM1 and RH on chromosome 1. Cytogenet Cell Genet 1985;40:7345.

14 Rogne S, Myklebost O, Stanley KK, Geurts van Kessel AHM. The gene for human complement $\mathrm{C} 9$ is on chromosome 5 . Genomics 1989;5:149-52.

15 Jeremiah SJ, Abbott CM, Murad Z, et al. The assignment of the genes coding for human complement components $\mathrm{C} 6$ and C7 to chromosome 5. Ann Hum Genet 1990;54:141-7.

16 Stanley KK, Kocher HP, Luzio JP, Jackson P, T schopp J. The sequence and topology of human complement component $\mathrm{C} 9$. $E M B O$ ₹ 1985;4:375-82.

17 Rogne S, Skretting G, Larsen F, et al. The isolation of a cDNA clone for human lecithin:cholesterol acyl transferase and its use to analyse the genes in patients with LCAT deficiency and fish eye disease. Biochem Biophys Res Commun 1987;148:1619.

18 Rogne S, Mevåg B, Gedde-Dahl T Jr, Myklebost O. Multiple RFLPs of human complement component C9 (C9) detected by TaqI. Nucleic Acids Res 1990;18:3112.

19 Olving JH, Olaisen B, Teisberg P, Gedde-Dahl T Jr, Thorsby E. Nonlinkage between $\mathrm{C} 6$ and chromosome 6 markers. Hum Genet 1977;37:125-9.

20 Olving JH, Olaisen B, Gedde-Dahl T Jr, Teisberg P. Genetic linkage relations of the sixth component of complement (C6). Hum Genet 1979;46:181-92. 
21 Hobart MJ, Lachmann PJ, Alper CA. Polymorphism of human C6. In: Properties of the biological fluids. Oxford: Pergamon Press, 1975: 575.

22 Olaisen B, Teisberg P, Gedde-Dahl T Jr, Moen T, Thorsby E. Complement loci of the HLA complex. Studies on families with intra-HLA cross-overs and haplotype associations. Hum Immunol 1981;2:247-54.

23 Morton NE. Sequential tests for the detection of linkage. $A m \mathcal{F}$ Hum Genet 1955;7:277-318.

24 Morton NE. Further scoring types in sequential linkage tests with a critical review of autosomal and partial sex-linkage in man. Am F Hum Genet 1957;9:55-7.

25 Skolnick MH, Willard HF, Menlove LA. Report of the committee on gene mapping by recombinant DNA techniques. Cytogenet Cell Genet 1984;37:210-48.
26 Conneally PM, Edwards JH, Kidd KK, Lalouel J-M, Ott J, White R. Report of the committee on methods of linkage analysis and reporting. Cytogenet Cell Genet 1985;40:356-9.

27 Hobart MJ, Joysey V, Lachmann PJ. Inherited structural variation and linkage relationships of $\mathrm{C} 7 . \mathcal{F}$ Immunogenet 1978;5:157-63.

28 Lachmann PJ, Hobart MJ, Woo P. Combined genetic deficiency of C6 and C7 in man. Clin Exp Immunol 1978;33:193203.

29 Karathanasis SK. Apolipoprotein multigene family: tandem organization of human apolipoprotein AI, CIII, and AIV genes. Proc Natl Acad Sci USA 1985;82:6374-8.

30 Myklebost O, Rogne S. A physical map of the apolipoprotein gene cluster on human chromosome 19. Hum Genet 1988;78:244-7. 